\title{
Local determinants of household gas and electricity consumption in Randstad region, Netherlands: application of geographically weighted regression
}

\author{
Bardia Mashhoodi $^{1,2}$ (D) Arjan van Timmeren ${ }^{1,2,3}$
}

Received: 5 February 2018/Revised: 5 July 2018/Accepted: 6 July 2018/Published online: 17 July 2018

(C) The Author(s) 2018

\begin{abstract}
The previous studies on household energy consumption (HEC) are based on an implicit assumption: the impact of geographic determinants on HEC is uniform across a given region, and such impacts could be unveiled regardless of geographic location of households in question. Consequently, these studies have searched for global determinants which explain HEC of all areas. This study aim at examining validity of this assumption in Randstad region by putting forward a question regarding households' gas and electricity consumption: are the determinants global, stationary across all the areas of the region, or local, varying from one location to another? By application of geographically weighted regression, impact of socioeconomic, housing, land cover and morphological indicators on HEC is studied. It is established that the determinants of HEC are local. This result led to second question: what are the main determinants of gas and electricity consumption in different neighborhoods of Randstad? The results show that variety of factors could be the most effective determinant of gas consumption in different neighborhoods: building age, household size and inhabitants' age, inhabitants' income and private housing tenure, building compactness. Whereas, in case of electricity consumption the picture is more deterministic: in most of the neighborhoods
\end{abstract}

Bardia Mashhoodi

b.mashhoodi@tudelft.nl

1 Chair of Environmental Technology and Design, Department of Urbanism, Faculty of Architecture and the Built Environment, Delft University of Technology Delft, Delft, The Netherlands

2 Gebouw 8, Julianalaan 134, 2628 BL Delft, The Netherlands

3 AMS Institute, Amsterdam, The Netherlands the most effective factors are inhabitants' income and private tenure.

Keywords Household energy consumption . Geographically weighted regression · Gas · Electricity . Randstad · Netherlands

\section{Introduction}

The level of household energy consumption (HEC) in Netherlands is high and unsustainable: calculated per capita and adjusted for climate, in 2013 HEC in Netherlands was about $8 \%$ higher than average EU-28 [1, 2]; Dutch households' greenhouse gas emission per capita was $37 \%$ higher than the EU-28 average [3]; and sales of gas in the residential and commercial sectors per capita was $202 \%$ higher than EU average [2,4]. Three geographical factors could be accounted for high level of HEC in Netherlands. First, the substantial dependency of HEC on natural gas largely due to the existence of the large amount of natural gas in the northern parts of the Netherlands, in particular the so-called 'Groningen' or 'Slochteren' gas field which, on its discovery in 1959, seemed abundant enough to satisfy Dutch (and other European countries') needs for natural gas. This assumption led to a nationwide implementation of natural gas infrastructure; all the households of the country has access to gas and electricity grid. Additionally, given the highly liberalized and competitive energy retail market, the price of energy for household, gas and electricity, is relatively low in Netherlands. In 2012 energy prices for households was 5\% lower than the European average [5], whereas GDP per capita was more than $30 \%$ higher [6]. In this respect, given the substantial share of HEC from total emission, $16 \%$ of 
total in 2015 [7], policies of Netherlands targeted reduction of HEC by introduction of in Third National Energy Efficiency Action Plan for the Netherlands [8]. The policy document introduces variety of incentives and regulation for curbing HEC which are applicable for all the locations of the Netherlands. The main focus of the introduced measures is improvement of dwellings' energy efficiency e.g. low interest loans for building insolation, tighter standards for new constructions, restrict measures for efficiency of heating and ventilation systems.

The necessity of reduction of HEC is also reflected between scholars. The existing body of literature on HEC is rich as plenty of previous studies have established links between HEC and variety of determinants among them socioeconomic characteristics, urban form, urban microclimate, housing. However, these studies are limited in scale. Most of the previous studies on HEC use surveys conducted at scale of individual dwellings. Therefore, the larger geographic pattern of HEC, and its geographic drivers, is barely studied. In this respect, missing the larger geographic patterns, all the previous studies are conducted based on an implicit assumption: determinants of HEC are identical in every and each dwelling regardless of its geographic location. In other words, it is assumed that the impact of geographic determinants on HEC is uniform across a given study area, and such impacts could be unveiled by application of aspatial methods. In this respect, vast majority of previous studies have ignored the fact that impact of a given determinant could vary from one location to another. Consequently, these studies bring forward onesize-fits-all type of recommendation for all the areas in question instead of location-specific ones.

The core objective of this study is to bridge this knowledge gap by putting forward two research questions: (a) are the effects of geographic determinant on households' gas and electricity consumption vary across the neighborhoods of Randstad region? In other words, are the determinants global, stationary across all the areas of the region, or local, varying from one location to another? (b) if the determinants are local, what are the main determinant of gas and electricity use in different neighborhoods of the region? To chase answers to these questions, this study apply geographically weighted regression (GWR) to examine the effect of a variety of socioeconomic, housing, land cover and morphological properties on household's gas and electricity consumption. In the next parts, first the previous studies on HEC are briefly reviewed. Then after, the methodology, case study and data of this research are described. Subsequently, results are presented and discussed. The paper ends up with a brief conclusions regarding scientific studies and policies on HEC.

\section{Previous studies on HEC}

Most of the previous studies on HEC are conducted at the scale of individual dwellings i.e. using household survey regardless of larger geographic pattern of HEC. At this scale, previous studies have shown that variety of factors can affect level of HEC: Inhabitants with higher income have a higher consumption [9, 10]; due to economies of scale, larger household size is associated with lower HEC $[11,12]$; age of the inhabitants, particularly presence of senior residents and children, affect HEC [9, 13]; presence of retired or disable inhabitants boost level of HEC [11]; HEC in different housing tenure, due to various systems of paying for energy bills as well as different level of investment in buildings, is significantly different [10, 14]; HEC soar in the building with higher age [9, 10]; landcover of the neighborhoods can affect land surface temperature and consequently $\operatorname{HEC}[15,16]$; Wind intensity affect air infiltration and exfiltration of buildings and thus HEC [17, 18]; building density alter HEC by its effect on compactness of dwellings [19, 20]; Rugosity affect effective wind speed and HEC in the neighborhoods [21]; buildings' surface-to-volume ratio impact HEC by affecting thermal exchange between dwellings [22, 23]; Population density affect HEC via altering level of urbanity and behavior of residents [13, 24]; and solar radiation affect HEC via impacting indoor temperature $[25,26]$.

Studies on geographic determinates of HEC (conducted on aggregated HEC in neighborhoods, cities, regions, etc.) are few in numbers, however plentiful in amount of information. These studies enhance a geographic understanding of HEC: the locations-specific determinants of HEC at different locations. For instance, a study on rural Chinese areas show that energy price and energy transportation (i.e. distance from coal sources) are among the main determinants of HEC. Furthermore, the study show these effect of vary in different geographies: energy transportation is significant only if the distances is greater than $20 \mathrm{~km}$; impact of energy price soar in high mountains [27]. A study on determinants of HEC in 64 European regions, so-called NUTS2 regions concluded that socioeconomic (income, education, unemployment, poverty) and contextual (e.g. climate) variables significantly affect HEC. The study show that impact of some determinates, e.g. disposable income, is common for all the regions. However that of some determinates vary due to regional development. For example, GDP has a positive effect on HEC of less developed region, due to achieving higher living standard, whereas it has a negative impact on HEC of more developed region, due to achieving higher energy efficiency [28]. A regional study on household's final energy use in the Netherlands show that quality of buildings and 
income has a greater impact on HEC of rural areas than urbanized areas. The study conclude that in the suburban areas population density is a significant determinant of HEC, whereas in highly urbanized areas household size or building density are the prominent determinants [29].

\section{Methodology}

Prior to application of GWR models, in order to examine the generalizable effects of the geographic determinants on HEC, two conventional linear regression models (OLS) are developed:

$y_{i}=\beta_{0}+\sum_{k} \beta_{k} x_{i k}+\varepsilon_{i}$

where $y_{i}$ represents the estimated value of HEC (gas or electricity consumption) in the location $i, \beta_{0}$ shows the intercept, $\beta_{k}$ denotes the coefficient slope of the independent variable $k, x_{i k}$ represents the value of independent variable $k$ in location $i$. $\varepsilon_{i}$ accounts for the random error term in location $i$. Subsequently, in order to examine the location-specific effects, two GWR models [Eq. (2)] are applied.

$y_{i}=\beta_{0}\left(\mu_{i}, \vartheta_{i}\right)+\sum_{k} \beta_{k}\left(\mu_{i}, \vartheta_{i}\right) x_{i k}+\varepsilon_{i}$

where $\left(\mu_{i}, \vartheta_{i}\right)$ represents the geographic coordination of location $i, \beta_{k}\left(\mu_{i}, \vartheta_{i}\right)$ and $\beta_{0}\left(\mu_{i}, \vartheta_{i}\right)$ are the local coefficient and intercept of independent variable $k$ estimated specific to location $i$. The local coefficients at location $i$ is calculated by [Eq. (3)]:

$\hat{\beta}(\mu, \vartheta)=\left(X^{T} W(\mu, \vartheta) X\right)^{-1} X^{T} W(\mu, \vartheta) y$

where $W(\mu, \vartheta)$ is the spatial weighting matrix which conceptualize the importance of adjacent neighborhoods of location $i$ :

$W_{i j}= \begin{cases}e^{\left(-d_{i j}^{2} / \theta_{i(k)}^{2}\right)}, & \text { if } d_{i j}<\theta_{i(k)} \\ 0, & \text { otherwise }\end{cases}$

where $W_{i j}$ denotes the weight of location $j$ for the estimation of the location $i$ coefficients, $d_{i j}$ is the geodesic distance between location $i$ and $j . \theta_{i(k)}$ is an adaptive bandwidth denoting distance from the $k$ th nearest neighbor. Using ArcGIS (version 10.2), the bandwidths of the models are specified so as to minimize the Akaike Information Criterion (AIC) of the GWR models.

The performance of GWR and OLS models are compared by means of five tests. First, adjusted $\mathrm{R}^{2}$ of the two models are compared. Second, by comparison between the AICc (corrected Akaike's Information Criterion) of the models. Typically, at least three points decrease in AICc is seen as a significant improvement (e.g. [30, 31]). Third, comparison of randomness of the distribution of the residuals of the models-validated by Moran's I Index. The index is a measure of spatial autocorrelation ranged between -1 and +1 ; value closer to zero shows more random distribution. Fourth, in order to examine whether the effect of the determinants on HEC vary across the study areas, stationary indices-proposed by Charlton et al. [32] — of independent variables are calculated. To do so, interquartile ranges of the standard error of coefficients in the GWR model are divided by twice the standard error of coefficients in the OLS model. If value of the stationary index is equal to or greater than one, it indicates that the effect of the given independent variable on HEC is spatially non-stationary. Fifth, ANOVA tests, to compare residuals of GWR and OLS models, are applied.

\section{Case study and data}

\subsection{Case study area and analysis area}

The spatial element used in this study are the buurten, spatial divisions defined by the Dutch central bureau of statistics (CBS) - what we call as neighborhood. The case study of this research — what we call as "study area"-is consisted of neighborhoods of the Randstad region. The Randstad is a highly urbanized metropolitan area located in the south west of the Netherlands consist of the four major cities of Amsterdam, Rotterdam, the Hague and Utrecht, and the areas between them-the so-called "green heart". In order to avoid the boundary-effect problem in GWR models, all the calculations are carried out on the "study area" plus a $20 \mathrm{~km}$ buffer-what we call as "analysis area". Although all calculations are carried out on the analysis area, ultimately merely the results obtained for "study areas" are taken into consideration (Fig. 1).

\subsection{Dependent variables}

The dependent variables of the study are gas and electricity consumption per capita within dwellings [33]. As the available data does not show the areas equipped with solar energy supply or district heating, the abnormal values of gas and electricity use needed to be filtered out (incidents with $z$-value $\leq-2.5$ or $z$-value $\geq+2.5$ ) Ultimately, the "analysis area" consists of 3514 neighborhoods and the "study area" of 2413 (Fig. 2a, b). The Moran's Index test show that high values of gas and electricity consumption (both in study and analysis area) are spatially clustered across the region. The respective Moran's I z-score is well beyond the threshold of 2.58 (which indicate spatially clustered pattern): 36.8 (in case of gas use in study area), 
Fig. 1 Location map of study area and analysis area
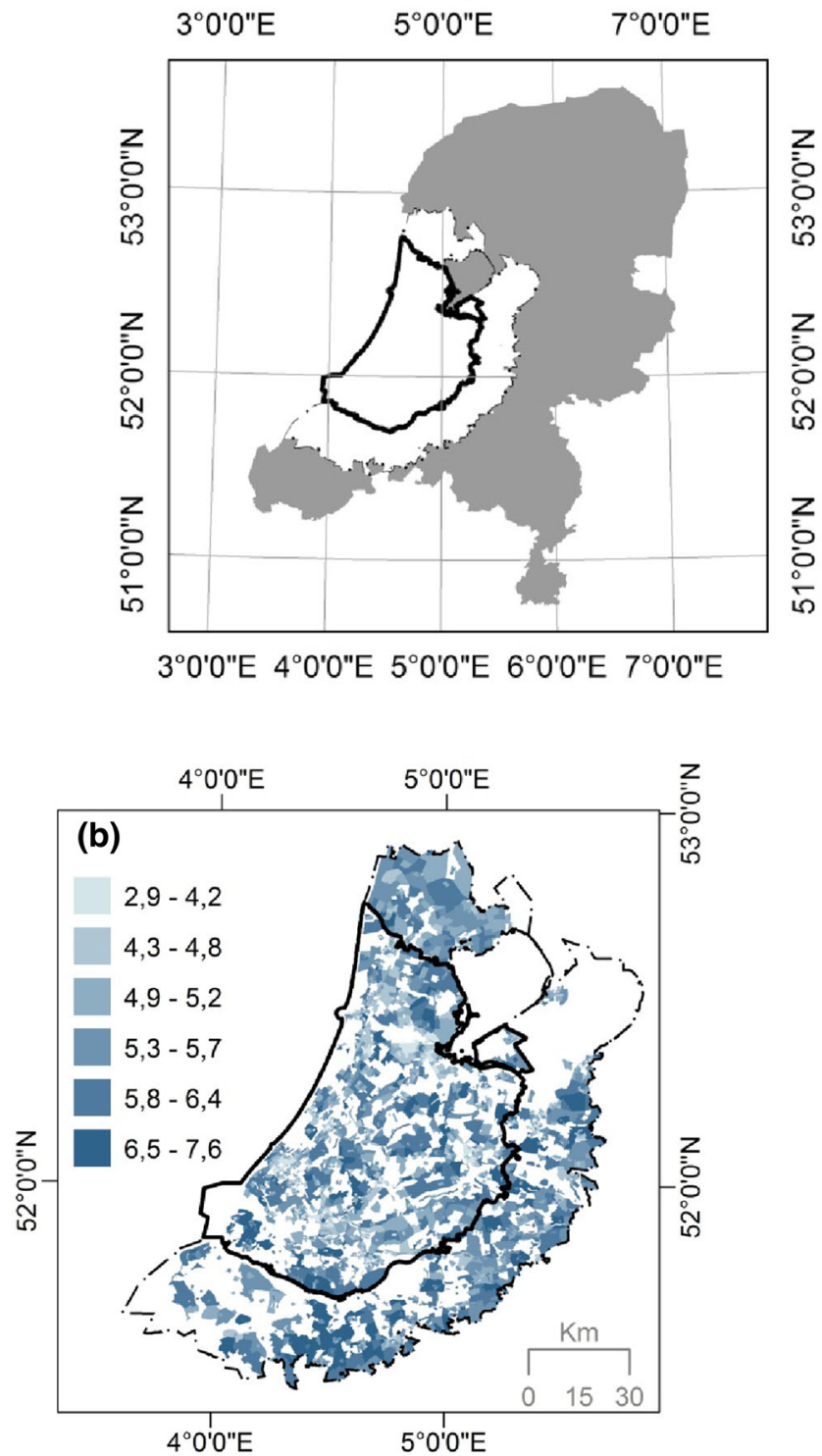

Fig. 2 Dependent variables of study: a annual gas consumption per capita 2013 (Mega Joule), b annual electricity consumption per capita 2013 (Mega Joule)

49.7 (in case of gas use in analysis area), 42.3 (in case of electricity use in study area), 57.6 (in case of electricity use in analysis area). Thus, as spatial variation is significant, application of GWR is essential for enhancing better understanding of such geographic pattern.

\subsection{Independent variables}

This study use five dependent variables. The variables compress the effect of 21 indicators by means of factor analysis. By choice of the 21 indicators, we tried to include all the potential effective factors without a priori selection (see Table 1). Socioeconomic and housing variables are taken from CBS, 2013 [25]. Land cover variables are extracted from a Bodemgebruik database, 2012 [34]. Building height database in the Netherlands, 3D BAG [35], is used to prepare a digital elevation model (DEM). Cell size of DEM is $10 \mathrm{~m}$. The latter in utilized to prepare urban form indicators. In the next part, a more detailed explanation of some of the variables is presented.

According to Adolphe [21], the variation of building height, or what he calls as rugosity, could have a significant effect on the urban microclimate. We calculated rugosity as the standard deviation of height values (including those with zero height) of DEM. The frontal area index $\left(\lambda_{f}\right)$ is the ratio of the total area of external building walls to the total area of the neighborhood. In order to calculate $\lambda_{\mathrm{f}}$, firstly external walls need to be identified. To do so, using 
Table 1 The five Independent variables of the study compress the effect of 21 indicators

\begin{tabular}{|c|c|c|c|c|c|}
\hline \multirow[t]{2}{*}{ Variables } & \multicolumn{5}{|l|}{ Factors } \\
\hline & $\begin{array}{l}\text { FAC1 population } \\
\text { density and built-up } \\
\text { areas }\end{array}$ & $\begin{array}{l}\text { FAC2 Income } \\
\text { and private } \\
\text { tenure }\end{array}$ & $\begin{array}{l}\text { FAC } 3 \text { Household size and } \\
\text { population younger than } 14 \text { years } \\
\text { old }\end{array}$ & $\begin{array}{l}\text { FAC4 } \\
\text { Building } \\
\text { age }\end{array}$ & $\begin{array}{l}\text { FAC5 } \\
\text { Building } \\
\text { density }\end{array}$ \\
\hline Built-up coverage $(\%)$ & .977 & -.089 & -.091 & -.177 & -.067 \\
\hline Building coverage ratio $(\%)$ & .905 & .075 & .005 & .177 & -.005 \\
\hline Green-coverage $(\%)$ & $-\underline{.891}$ & .086 & .075 & .216 & -.065 \\
\hline Frontal area index & .750 & .021 & .064 & .201 & .291 \\
\hline $\begin{array}{l}\text { Population-density (persons per } \\
\mathrm{km}^{2} \text { ) }\end{array}$ & .621 & -.165 & .231 & .125 & .270 \\
\hline Income per capita (euro) & .126 & .892 & -.304 & -.113 & .121 \\
\hline Public-rent $(\%)$ & .050 & -.780 & -.070 & -.047 & .183 \\
\hline Property-value (euro) & -.276 & .739 & -.058 & .020 & -.085 \\
\hline Disability $(\%)$ & -.147 &.- .631 & -.266 & -.024 & .088 \\
\hline Unemployment (\%) & .221 &.$- \underline{481}$ & -.056 & -.040 & -.014 \\
\hline Population ages $65+(\%)$ & .019 & .037 & $-\underline{.891}$ & -.067 & -.064 \\
\hline Population ages $0-14(\%)$ & -.020 & .002 & .748 & -.343 & -.125 \\
\hline Household-size & -.167 & .218 & .478 & -.338 & -.380 \\
\hline Building median age & -.061 & .110 & .046 & $\underline{.855}$ & .119 \\
\hline $\begin{array}{c}\text { Floor area after introduction of } \\
1988 \text { building standards }(\%)\end{array}$ & -.013 & .205 & .283 & $-\underline{.674}$ & .267 \\
\hline $\begin{array}{l}\text { Solar radiation per building } \\
\text { volume }\left(\mathrm{WH} / \mathrm{m}^{3}\right)\end{array}$ & .028 & .089 & -.055 & .002 & $-\underline{.919}$ \\
\hline Rugosity & .288 & -.021 & .026 & .139 & .751 \\
\hline $\begin{array}{l}\text { Solar radiation on } \\
\text { neighbourhood }\left(\mathrm{WH} / \mathrm{m}^{2}\right)\end{array}$ & -.260 & -.031 & -.066 & -.273 & $-\underline{.741}$ \\
\hline Aerodynamic roughness length & .175 & -.168 & -.001 & -.143 & .721 \\
\hline Floor area ratio $(\%)$ &. .484 & .099 & .067 & .306 & $\underline{.532}$ \\
\hline $\begin{array}{l}\text { Buildings' surface to volume } \\
\text { ratio }\left(\mathrm{m}^{-1}\right)\end{array}$ & .067 & -.005 & .191 & .138 & -.379 \\
\hline
\end{tabular}

The pattern matrix show the loading of independent variables on the indicators. Coefficients with absolute value $>0.400$ are marked boldunderline

ArcGIS 10.2 Focal Flow tool, $3 \times 3$ immediate neighbors of each DEM cell is studied. It is determined that which sides of each DEM cell are external wall (i.e. are not occupied with a building cell or are occupied with a shorter building). The obtained information is used for calculation of total amount of external walls at each DEM cell. This has been instrumented for calculation of $\lambda_{\mathrm{f}}$ and subsequently aerodynamic roughness length (ARL). ARL is the height in which the effective wind speed is theoretically zero. Higher values of ARL correspond with lower wind intensity [36]. The morphometric model introduced by Macdonald et al. [37], one of the most comprehensive models according to a review by Grimmond and Oke [38], is used:

$\frac{Z_{d}}{Z_{H}}=1+\alpha^{-B C R}(B C R-1)$
$\frac{Z_{0}}{Z_{H}}=\left(1-\frac{Z_{d}}{Z_{H}}\right) \exp \left(-\left(\frac{0.5 \beta C_{D} \lambda_{f}}{k^{2}}\left(1-\frac{Z_{d}}{Z_{H}}\right)\right)^{-0.5}\right)$

where $\mathrm{Z}_{0}$ is aerodynamic roughness length for momentum, $Z_{d}$ is zero-plane displacement height, $Z_{H}$ is height of roughness element $(\mathrm{m}), \mathrm{BCR}$ is building coverage ratio, $\lambda_{\mathrm{f}}$ frontal area index, $\alpha=4.43, \beta=1.0, \mathrm{k}=0.4$, and $\mathrm{C}_{\mathrm{D}} \cong 1$.

Deploying the Arcgis 10.2 solar radiation toolbox, the DEM model is used to calculate solar radiation (SLR) on summer (21 June) and winter (21 December) solstice of 2013. The average value of the 2 days is used to calculate two variables: solar radiation per square meters of neighborhoods' surface [solar radiation on neighborhood (WH/ $\left.\mathrm{m}^{2}\right)$ ] and per cubic meters of the buildings [solar radiation per building volume $\left.\left(\mathrm{WH} / \mathrm{m}^{3}\right)\right]$. 
To address the potential multicollinearity between the 21 indicators, factor analysis, with extraction method of principal component analysis and rotation method of Oblimin with Kaiser Normalization, is deployed. As result, the effect of the indicators is compressed in five factors (Table 1). As the extraction method is principal component analysis, a small level of independence between the obtained factors is tolerated. Consequently, one of the initial variables, floor area ratio (FAR), has made contribution to two of the factors. Whereas the rest of 20 variables have merely contributed to one factor. The factors explain almost $75 \%$ of the total variance of the 21 variables. The first factor, FACl Population density and builtup areas, is positively loaded onto built up coverage (\%), BCR, $\lambda_{\mathrm{f}}$, population density and FAR, and negatively on green-coverage (\%). FAC2 Income and private tenure, is positively loaded onto income per capita and property value, and negatively loaded onto disability (\%), unemployment (\%) and public rental (\%). FAC3 Household size and population younger than 14 years old, is positively loaded onto population ages 0-14 (\%) and household-size, and negatively loaded onto population ages $65+(\%)$. FAC4 Building age, is positively loaded onto building median age, and negatively onto floor area after introduction of 1988 building standards (\%). FAC5 Building compactness, is and positively onto FAR, rugosity and ARL and negatively onto solar radiation per building volume $\left(\mathrm{WH} / \mathrm{m}^{3}\right)$ and solar radiation on neighborhood $\left(\mathrm{WH} / \mathrm{m}^{2}\right)$.

\section{Results}

\subsection{Comparison between performance of GWR and OLS models}

A comparison between adjusted $R^{2}$ of the two OLS and GWR models, shows that all three of the GWR models have a better goodness-of-fit (Table 2). The adjusted $\mathrm{R}^{2}$ of the GWR model of gas consumption is some $15 \%$ higher than that of OLS. The corresponding number for the electricity consumption models is about $17 \%$. The local $\mathrm{R}^{2}$ of the GWR models (Fig. 3) show that in more than $76 \%$ of the areas estimation of gas and electricity consumption produced a better $\mathrm{R}^{2}$ than OLS model.

The comparison between the AICc (corrected Akaike's Information Criterion) of the GWR and OLS models shows a remarkable improvement in the case of GWR models. The results show that the residuals of GWR models are more randomly distributed rather than those of OLS models; the Moran's Indices of the GWR models are substantially closer to zero than those of OLS models. The stationary indices of all the independent variables of the GWR models are greater than 1 . This indicates that the effect of the variables on HEC is spatially non-stationary (Table 2).

ANOVA test of the residuals in GWR and OLS models indicate a significant improvement in case of GWR models (Table 3).

\subsection{Local determinants of HEC}

Figure 3 shows the estimated local standardized coefficients of the independent variables in the two GWR models. According to the results of the GWR models, the percentage of the areas with a significant coefficient of FAC1 Population density and built-up areas is rather small (Fig. $4 \mathrm{a}, \mathrm{f}$ ). In the case of the gas consumption model the impact of the factor is significant-at $p$ value $<0.1$ levelin $63 \%$ of the areas. In case of electricity consumption the percentages is $45 \%$. However, the magnitude of the significant coefficients is considerable in a substantial portion of the areas. The significant coefficients are negatively signed. The magnitude of the coefficient is almost similar in case of the two models.

The results of the GWR models of gas and electricity consumption show that in almost all of the areas, the coefficients of FAC2 Income and private tenure are significant (Fig. 4b, g). Roughly speaking, signs of all the significant coefficients are positive. The largest effect of the factor is observed in the case of electricity consumption model (according to the mean standardized coefficient of the GWR model).

The results of GWR models of gas and electricity consumption show that in more than $97 \%$ of the areas, the coefficients of FAC3 Household size and population younger than 14 years old are significant (Fig. 4c, h). The sign of all the significant coefficients is negative. The magnitude of the coefficients is almost similar in the two models.

The results show FAC4 Building age has significant effect on a gas consumption in more than $95 \%$ of the areas (Fig. 4d, i). However, In case of electricity consumption the factor is not effective in almost $70 \%$ of the areas. The magnitude of the coefficients (assessed by the mean value of the GWR models) is remarkably high in the case of gas consumption model. The sign of all the coefficients is positive. In the electricity consumption model, though positive, the magnitude of the coefficients is close to zero.

According to the results of the GWR models, in the case of the gas consumption model, the impact of FAC5 Building compactness is significant in $70 \%$ of the areas (Fig. $4 \mathrm{e}, \mathrm{j}$ ). In the case of electricity consumption, the corresponding number is $44 \%$. The coefficients, except in the case of $5 \%$ of the areas in electricity consumption model, are negative. The largest magnitude of the effect is observed in the case of the gas consumption model. 
Table 2 Diagnostic statistics in GWR and OLS models

\begin{tabular}{|c|c|c|c|c|c|c|}
\hline & \multicolumn{6}{|c|}{ Dependent variable } \\
\hline & \multicolumn{3}{|c|}{ Gas consumption } & \multicolumn{3}{|c|}{ Electricity consumption } \\
\hline & $\begin{array}{l}\text { GWR } \beta \\
\text { mean }\end{array}$ & OLS $\beta$ & $\begin{array}{l}\text { Stationary } \\
\text { index }\end{array}$ & $\begin{array}{l}\text { GWR } \beta \\
\text { mean }\end{array}$ & OLS $\beta$ & $\begin{array}{l}\text { Stationary } \\
\text { index }\end{array}$ \\
\hline \multicolumn{7}{|l|}{ Independent variables } \\
\hline FAC1 population density and built-up areas & -0.173 & $-0.193 * * *$ & 1.118 & -0.150 & $-0.211 * * *$ & 1.195 \\
\hline FAC2 Income and private tenure & 0.431 & $0.400 * * *$ & 1.770 & 0.594 & $0.560 * * *$ & 1.751 \\
\hline $\begin{array}{l}\text { FAC } 3 \text { Household size and population younger than } 14 \\
\text { years old }\end{array}$ & -0.433 & $-0.477 * * *$ & 1.141 & -0.396 & $-0.405 * * *$ & 1.132 \\
\hline FAC4 Building age & 0.451 & $0.377 * * *$ & 2.262 & 0.072 & $0.024 *$ & 2.239 \\
\hline FAC5 Building density & -0.250 & $-0.321 * * *$ & 2.620 & -0.108 & $-0.222 * * *$ & 2.616 \\
\hline R-squared & 0.8237 & 0.6787 & & 0.7915 & 0.6272 & \\
\hline Adjusted R-squared & 0.7880 & 0.6782 & & 0.7502 & 0.6266 & \\
\hline $\mathrm{AICc}$ & 4918.83 & 5995.77 & & 5486.74 & 6518.44 & \\
\hline Residuals Moran's I & -0.0065 & 0.2709 & & 0.0082 & 0.2349 & \\
\hline Neighbours & 108 & & & 110 & & \\
\hline
\end{tabular}

$\beta$ denotes standardized coefficient

$* p$ value $<0.05 ; * * p$ value $<0.01 ; * * p$ value $<0.001$
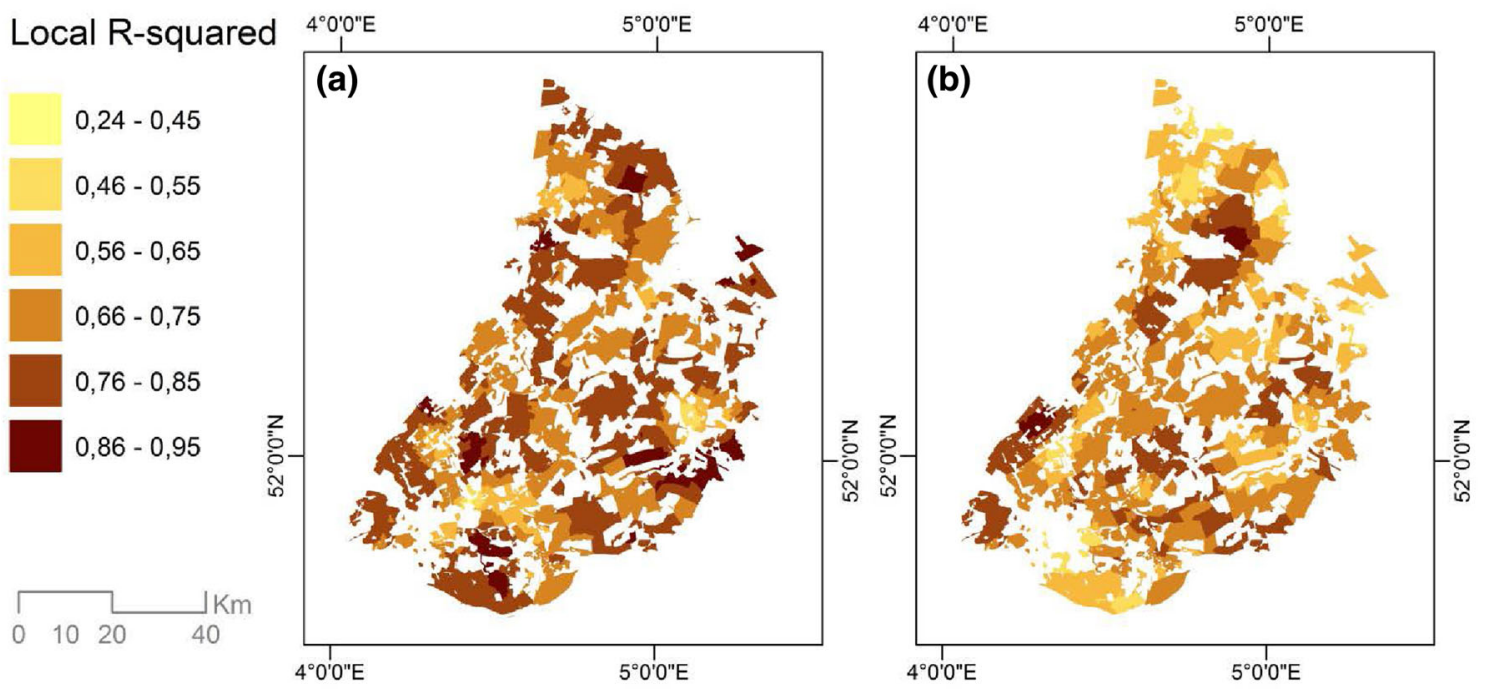

Fig. 3 Local adjusted R-squared of GWR estimation of: a gas consumption, b electricity consumption

Table 3 ANOVA test of residuals of GWR and OLS models

\begin{tabular}{|c|c|c|c|c|c|c|c|c|}
\hline & \multicolumn{8}{|c|}{ Dependent variable } \\
\hline & \multicolumn{4}{|c|}{ Gas consumption } & \multicolumn{4}{|c|}{ Electricity consumption } \\
\hline & $D f$ & Sum Sq & Mean Sq & $\mathrm{F}$ value & $D f$ & Sum Sq & Mean Sq & $\mathrm{F}$ value \\
\hline OLS residuals & 6 & 1128.78 & & & 6 & 1309.8 & & \\
\hline GWR improvement & 92.037 & 285.03 & 3.0969 & & 90.297 & 287.78 & 3.187 & \\
\hline GWR residuals & 3415.963 & 843.75 & 0.247 & 12.538 & 3417.703 & 1022.02 & 0.299 & 10.658 \\
\hline
\end{tabular}

F values are significant at $p$ value $<0.001$ 
Dependent Variable: gas consumption
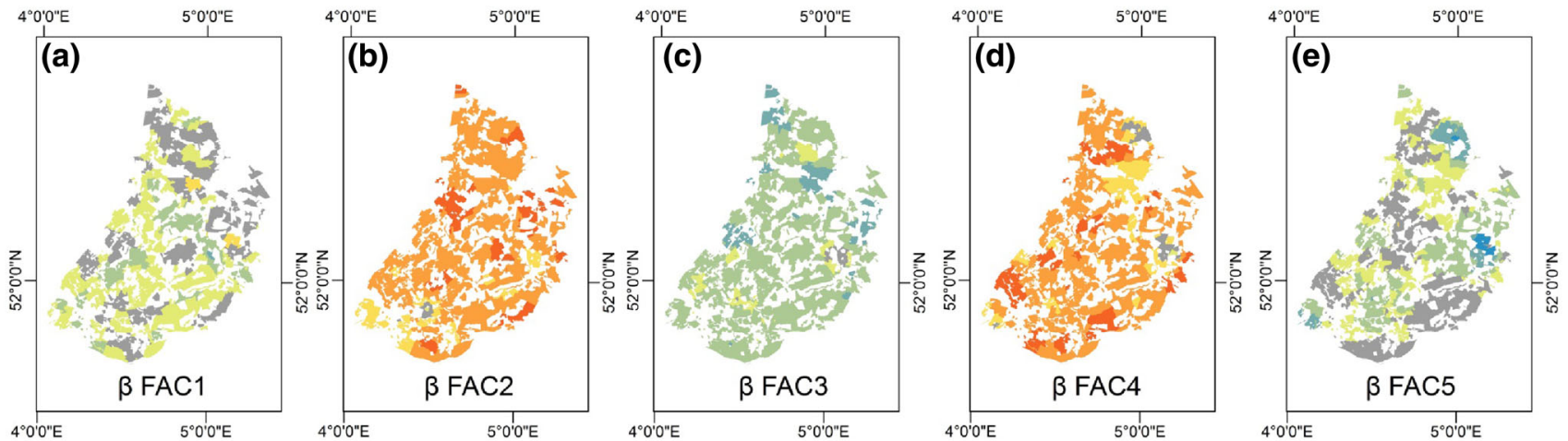

Dependent Variable: electricity consumption
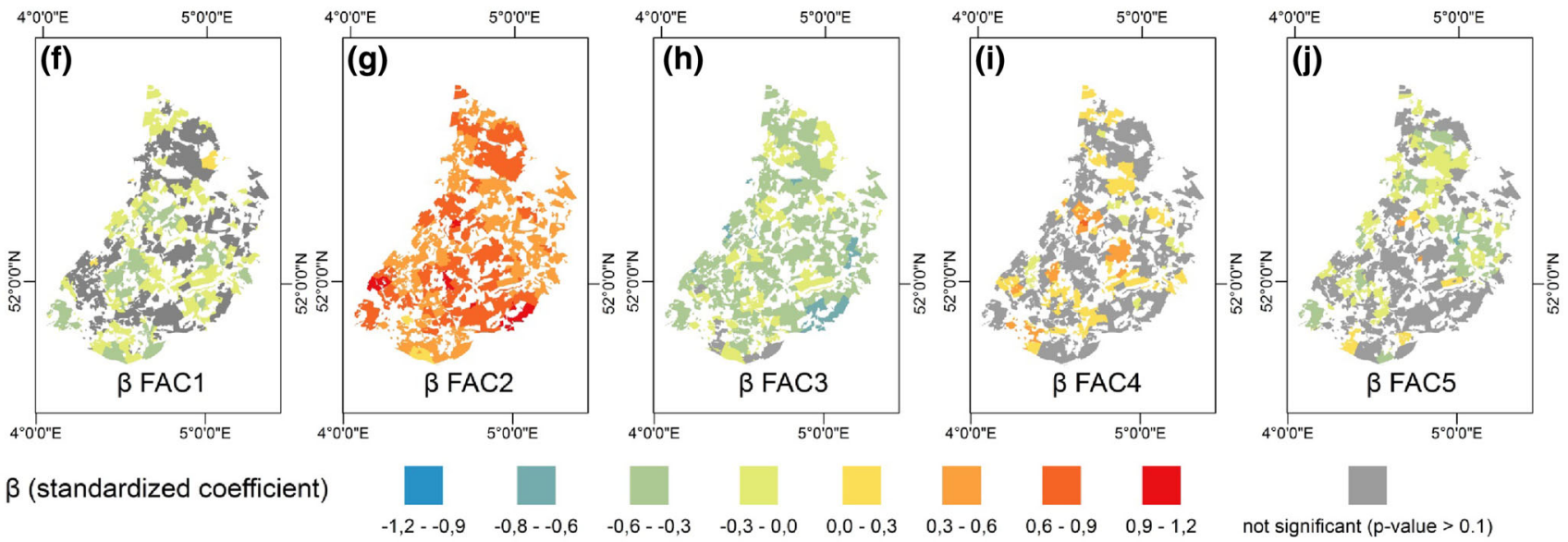

$\beta$ (standardized coefficient)

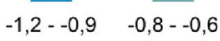

$-0,6--0,3$

$-0,3-0,0 \quad 0,0-0,3$

not significant $(p$-value $>0.1)$

Fig. 4 Local standardized coefficients: a-d gas consumption model, $\mathbf{f}-\mathbf{j}$ electricity consumption model

Figure 4 illustrates the largest local standardized coefficients (in absolute value) - what we call as the most effective local determinant-in different neighborhoods of the study area. The results show that, variety of factors could be the most effective determinant of gas consumption in different neighborhoods: FAC4 Building age in $37 \%$ of the neighborhoods, FAC3 Household size and population younger than 14 years old in $29 \%$ of the neighborhoods, FAC2 Income and private tenure in $23 \%$ of the neighborhoods, FAC5 Building compactness in $11 \%$ of the neighborhoods (Fig. 5a). In case of electricity use model, the picture is more deterministic: in $84 \%$ of the neighborhoods FAC2 Income and private tenure is the most effective factors. In the rest of the areas FAC3 Household size and population younger than 14 years old is found to be the most effective (Fig. 5b).

\section{Discussion}

The results of GWR models of gas and electricity consumption show that, in almost all the neighborhoods, sign of the coefficients is similar. However, the magnitude of the coefficients remarkably vary across the neighborhoods. The coefficients of FAC1 Population density and built-up areas are negative in almost all the areas. This could be due to higher air temperature, consequent to higher surface temperature, in the neighborhoods with higher percentage of built-up areas (similar to what is suggested by [20]). Also the residents of areas with higher population density, say more urbanized, could be more engaged with outdoor activities and spend less time within their dwellings. This could significantly reduce HEC (similar to the conclusion drawn by $[39,40])$. The coefficients of FAC2 Income and private tenure are positive in all of the neighborhoods. Presumably, high-income residents live in larger dwellings and possess more appliances at their homes (similar to conclusion drawn by [41]). All the local coefficients of FAC3 Household size and population younger than 14 


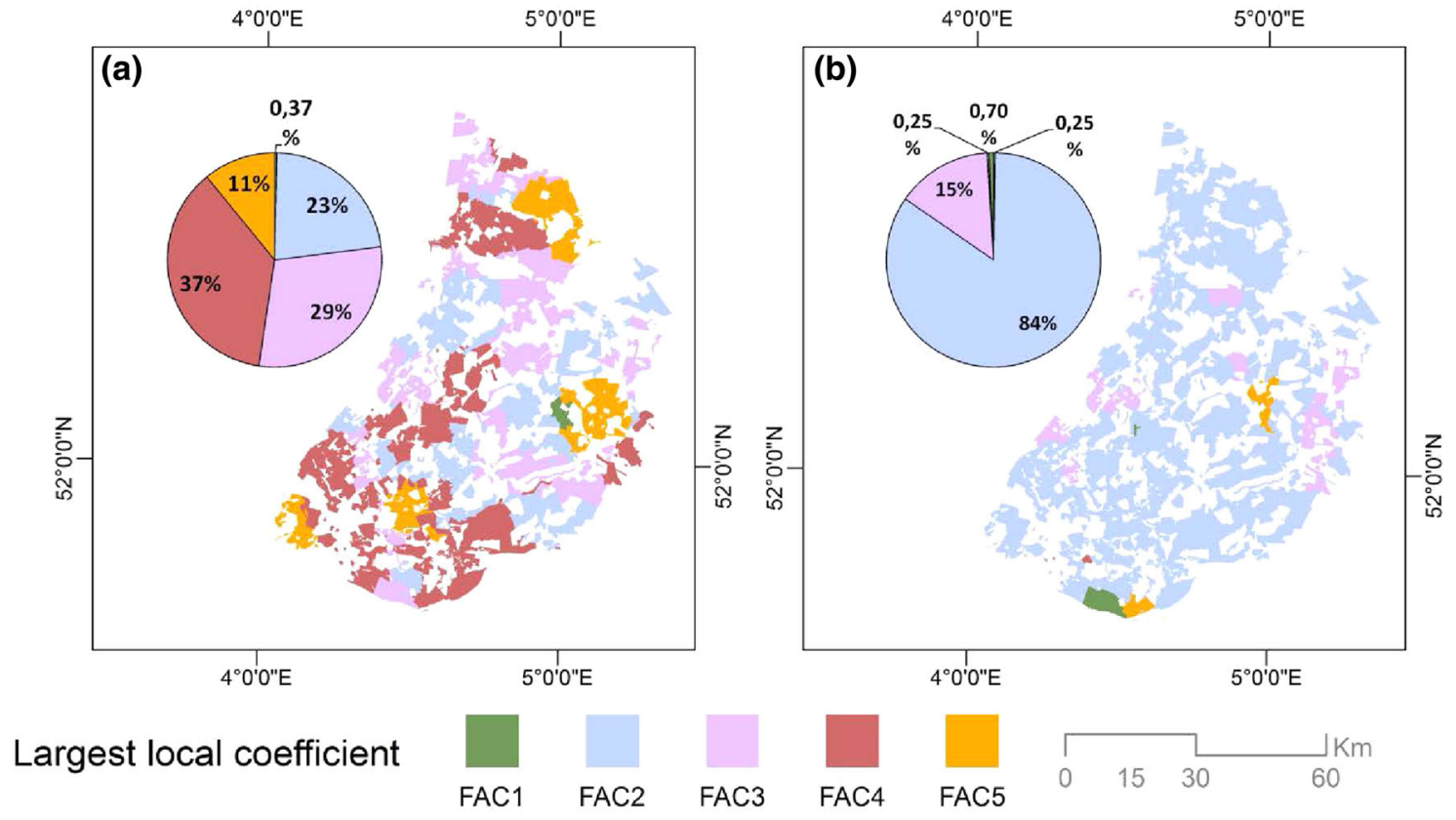

Fig. 5 The most effective local determinants—-largest local standardized coefficients (in absolute value)—of: a gas consumption, b electricity consumption

years old are negative. This could be due to economies of scale-as suggested by variety of previous studies (e.g. [42]).

Increase in FAC4 Building age has a large impact on increasing gas consumption. This is presumably due to lower energy efficiency of buildings (as concluded by variety of previous studies e.g. [23]). The effect of the factor on electricity consumption is not significant in most of the neighborhoods. However, if significant, the sign of coefficients are positive. Almost all of the local coefficients of FAC5 Building compactness are negative. This could be due to compactness of buildings and higher heat exchange between the dwellings in the neighborhoods with higher FAR (as concluded by variety of authors among them [10]). It also could be due to lower wind intensity (associated with high ARL) which reduce air infiltration/exfiltration and therefore buildings' thermal loss [18]. Additionally, lower solar radiation in the neighborhoods with higher FAC5 Building compactness, could reduce electricity consumption for cooling and ventilating [43].

The results show that variety of factors could be the most effective determinant of gas consumption in different neighborhoods. Whereas, in case of electricity consumption FAC2 Income and private tenure is the most effective determinant in vast majority of the neighborhoods. This could be explained by different final end-uses of gas and electricity in residential sector.

Eurostat data on final energy consumption of Dutch households in in 2015 [44], show that gas was the main source for space heating (87\%) and warm water (90\%). In this respect, the results of this study is in line with those of previous studies which show space and water heating could be affected by variety of determines among them occupant characteristics(e.g. [45]), building characteristics (e.g. [46]), housing tenure (e.g. [47]), urbanization rate (e.g. [48]), and number of dwellings per buildings (e.g. [49]). When it comes to electricity consumption, more than $50 \%$ of households' consumption is for lightening and appliances [44]. In this respect the results of this study is in line with previous studies which suggest that households with higher income consume more electricity for lighteningdue to owing larger dwellings-and appliances-due to possession of greater number of devices (e.g. [41]).

\section{Conclusion}

HEC has been of interest of many researchers and policy makers in the last decades. However, there is an eminent knowledge gap in the existing body of literature on HEC: all the previous studies have implicitly presumed that HEC could be explained by set of spatial stationary reasons and therefore has tried to unveil such everywhere-true reasons. The results of this study show that such presumption is questionable. It is obtained that, in the Randstad region, the of effects of socioeconomic, housing, land cover and morphological indicators on HEC vary from one location to another. In this respect, the main conclusion of this research is: in order to provide a better understanding of 
HEC, studies in this field need to search for the location specific factors which affect HEC in a given neighborhood.

It is also obtained that GWR models provide a better estimation of HEC rather than the OLS models. Previous studies on HEC have applied a wide range of aspatial techniques e.g. machine learning, linear regression, structural equation models, simulation models (see the review [50]). However, HEC studies lag behind in application of spatial econometrics methods. This studies concludes that HEC studies need to be enriched by further application of spatial statistics.

The results of this study also has a policy implication. By application of GWR, It is established that variety of factors could be the main determinants of level of gas and electricity consumption in different neighborhoods. This suggests that policy making regarding HEC needs a shift in perspective: one-size-fits-all type policies need to be enriched by introduction of location-specific strategies. By proposing such strategies, policy makers could optimally prioritize different incentives and obligations in different neighborhoods. Additionally, the policies as like Third National Energy Efficiency Action Plan [8] need to break through the narrow perspective of building energy efficiency, and take socioeconomic and morphological aspects into their consideration. Another policy implication regards the effect of FAR on household energy consumption, particularly gas use, within dwellings. It is obtained that FAR has a dual impact on consumption: On one hand FAR is associated with level of urbanity (i.e. more population density and built up surfaces), on the other hand FAR affect level of compactness (i.e. lower wind speed and solar radiation). Considering construction of 500,000 new dwellings in Randstad region according to 2014 vision [51], further studies need to assess the impact of this extra FAR on energy household energy consumption.

Further studies need to adopt the existing methods for studying microclimate factors -i.e. air and surface temperature, humidity - to enrich the estimates of HEC (similar to what is applied by [52-54]). Additionally, the effect of ever growing urbanization patterns (similar to that of $[55,56])$ on HEC need to be further studied. Further research could also seek for a comprehensive framework which combine HEC with potential locations for energy production (similar to the study by [57]). The last, in this study the determinant of gas and electricity consumption have been independently studied, the further studies could investigate the spatial autocorrelation between the two (similar to the methodology used by [58]).

Acknowledgements This study is part of DCSMART project founded in the framework of the joint programming initiative ERA-Net Smart Grids Plus, with support from the European Union's Horizon 2020 research and innovation program.

\section{Compliance with ethical standards}

Conflict of interest The authors declare that they have no conflict of interest.

Open Access This article is distributed under the terms of the Creative Commons Attribution 4.0 International License (http://crea tivecommons.org/licenses/by/4.0/), which permits unrestricted use, distribution, and reproduction in any medium, provided you give appropriate credit to the original author(s) and the source, provide a link to the Creative Commons license, and indicate if changes were made.

\section{References}

1. Odyssee-Mure Key Indicators. (2017). http://www.indicators. odyssee-mure.eu/online-indicators.html. Accessed July 24, 2017.

2. Eurostat. (2017). http://ec.europa.eu/eurostat/web/populationdemography-migration-projections/population-data/database. Accessed July 24, 2017.

3. Eurostat. (2016). http://ec.europa.eu/eurostat/statistics-explained/ index.php/File:Greenhouse_gas_emissions_by_economic_activ ity,_2013_(thousand_tonnes_of_CO2_equivalents)_YB16.png. Accessed July 24, 2017.

4. Eurogas. (2013). Statistical report 2013. http://www.eurogas.org/ uploads/media/Eurogas_Statistical_Report_2013.pdf. Accessed July 24, 2017.

5. Deloitte Conseil. (2015). European market reform, profile of Netherlands. https://www2.deloitte.com/content/dam/Deloitte/ global/Documents/Energy-and-Resources/gx-er-market-reformnetherlands.pdf. Accessed March 10, 2017.

6. Trading Economics. (2017). http://www.tradingeconomics.com/ european-union/gdp-per-capita, accessed March 10, 2017.

7. Eurostat. (2018). http://ec.europa.eu/eurostat/statistics-explained/ index.php?title=Greenhouse_gas_emissions_by_industries_and_ households\&oldid=177665. Accessed February 22, 2018.

8. Ministry of Economic Affairs. (2014). Third National Energy Efficiency Action Plan for the Netherlands. https://ec.europa.eu/ energy/sites/ener/files/documents/NEEAP_2014_nl-en.pdf. Accessed July 31, 2017.

9. Yun, G. Y., \& Steemers, K. (2011). Behavioural, physical and socio-economic factors in household cooling energy consumption. Applied Energy, 88(6), 2191-2200.

10. Druckman, A., \& Jackson, T. (2008). Household energy consumption in the UK: A highly geographically and socio-economically disaggregated model. Energy Policy, 36(8), 3177-3192.

11. Fong, W. K., Matsumoto, H., Lun, Y. F., \& Kimura, R. (2007). Influences of indirect lifestyle aspects and climate on household energy consumption. Journal of Asian Architecture and Building Engineering, 6(2), 395-402.

12. Lenzen, M., Wier, M., Cohen, C., Hayami, H., Pachauri, S., \& Schaeffer, R. (2006). A comparative multivariate analysis of household energy requirements in Australia, Brazil, Denmark, India and Japan. Energy, 31(2), 181-207.

13. York, R. (2007). Demographic trends and energy consumption in European Union Nations, 1960-2025. Social Science Research, 36(3), 855-872.

14. Tso, G. K., \& Yau, K. K. (2003). A study of domestic energy usage patterns in Hong Kong. Energy, 28(15), 1671-1682.

15. Madlener, R., \& Sunak, Y. (2011). Impacts of urbanization on urban structures and energy demand: What can we learn for urban energy planning and urbanization management? Sustainable Cities and Society, 1(1), 45-53. 
16. Georgakis, C., \& Santamouris, M. (2006). Experimental investigation of air flow and temperature distribution in deep urban canyons for natural ventilation purposes. Energy and Buildings, 38(4), 367-376.

17. Sanaieian, H., Tenpierik, M., van den Linden, K., Seraj, F. M., \& Shemrani, S. M. M. (2014). Review of the impact of urban block form on thermal performance, solar access and ventilation. Renewable and Sustainable Energy Reviews, 38, 551-560.

18. Van Moeseke, G., Gratia, E., Reiter, S., \& De Herde, A. (2005). Wind pressure distribution influence on natural ventilation for different incidences and environment densities. Energy and Buildings, 37(8), 878-889.

19. Ko, Y., \& Radke, J. D. (2014). The effect of urban form and residential cooling energy use in Sacramento, California. Environment and Planning B: Planning and Design, 41(4), 573-593.

20. Ewing, R., \& Rong, F. (2008). The impact of urban form on US residential energy use. Housing Policy Debate, 19(1), 1-30.

21. Adolphe, Luc. (2001). A simplified model of urban morphology: Application to an analysis of the environmental performance of cities. Environment and Planning B: Planning and Design, 28(2), 183-200.

22. Rode, P., Keim, C., Robazza, G., Viejo, P., \& Schofield, J. (2014). Cities and energy: Urban morphology and residential heat-energy demand. Environment and Planning B: Planning and Design, 41(1), 138-162.

23. Steemers, K., \& Yun, G. Y. (2009). Household energy consumption: A study of the role of occupants. Building Research \& Information, 37(5-6), 625-637.

24. Chen, Y. J., Matsuoka, R. H., \& Liang, T. M. (2017). Urban form, building characteristics, and residential electricity consumption: A case study in Tainan City. Environment and Planning B: Urban Analytics and City Science. https://doi.org/10.1177/ 2399808317690150.

25. O’Brien, W. T., Kennedy, C. A., Athienitis, A. K., \& Kesik, T. J. (2010). The relationship between net energy use and the urban density of solar buildings. Environment and Planning B: Planning and Design, 37(6), 1002-1021.

26. Mihalakakou, G., Santamouris, M., \& Tsangrassoulis, A. (2002). On the energy consumption in residential buildings. Energy and Buildings, 34(7), 727-736.

27. Sun, W., Han, X., Sheng, K., \& Fan, J. (2012). Geographical differences and influencing factors of rural energy consumption in Southwest mountain areas in China: A case study of Zhaotong City. Journal of Mountain Science, 9(6), 842-852.

28. Borozan, D. (2018). Regional-level household energy consumption determinants: The European perspective. Renewable and Sustainable Energy Reviews, 90, 347-355.

29. Mashhoodi, B. (2018). Spatial dynamics of household energy consumption and local drivers in Randstad, Netherlands. Applied Geography, 91, 123-130.

30. Gao, J., \& Li, S. (2011). Detecting spatially non-stationary and scale-dependent relationships between urban landscape fragmentation and related factors using geographically weighted regression. Applied Geography, 31(1), 292-302.

31. Hu, S., Yang, S., Li, W., Zhang, C., \& Xu, F. (2016). Spatially non-stationary relationships between urban residential land price and impact factors in Wuhan city, China. Applied Geography, 68, 48-56.

32. Charlton, M., Fotheringham, S., \& Brunsdon, C. (2003). Software for geographically weighted regression. Spatial Analysis Research Group, Department of Geography, University of Newcastle.

33. Statistics Netherlands. (2014). Wijk- en Buurtkaart 2013. Den Haag/Heerlen. https://www.cbs.nl/nl-nl/dossier/nederland-regio naal/geografische\%20data/wijk-en-buurtkaart-2013. Accessed February 1, 2018.
34. Bodemgebruik. (2012). National Georegister. http://www.natio naalgeoregister.nl/geonetwork/srv/dut/search\#109c2856f-854144c0-9621-44d496f3990d. Accessed June 28, 2016.

35. Esri Netherlands. (2016). $3 D$ BAG. http://www.esri.nl/nl-NL/ news/nieuws/sectoren/nieuw-in-arcgis-voor-leefomgeving. Accessed March 9, 2017.

36. Landsberg, H. E. (1981). The urban climate (Vol. 28). Cambridge: Academic Press.

37. Macdonald, R. W., Griffiths, R. F., \& Hall, D. J. (1998). An improved method for the estimation of surface roughness of obstacle arrays. Atmospheric Environment, 32(11), 1857-1864.

38. Grimmond, C. S. B., \& Oke, T. R. (1999). Aerodynamic properties of urban areas derived from analysis of surface form. Journal of Applied Meteorology, 38(9), 1262-1292.

39. Heinonen, J., Jalas, M., Juntunen, J. K., Ala-Mantila, S., \& Junnila, S. (2013). Situated lifestyles: I. How lifestyles change along with the level of urbanization and what the greenhouse gas implications are-A study of Finland. Environmental Research Letters, 8(2), 025003.

40. Yu, B., Zhang, J., \& Fujiwara, A. (2013). A household time-use and energy-consumption model with multiple behavioral interactions and zero consumption. Environment and Planning B: Planning and Design, 40(2), 330-349.

41. Yohanis, Y. G., Mondol, J. D., Wright, A., \& Norton, B. (2008). Real-life energy use in the UK: How occupancy and dwelling characteristics affect domestic electricity use. Energy and Buildings, 40(6), 1053-1059.

42. O'Neill, B. C., \& Chen, B. S. (2002). Demographic determinants of household energy use in the United States. Population and Development Review, 28, 53-88.

43. Bessec, M., \& Fouquau, J. (2008). The non-linear link between electricity consumption and temperature in Europe: A threshold panel approach. Energy Economics, 30(5), 2705-2721.

44. Eurostat. (2018). Energy consumption in households-Statistics explained. http://ec.europa.eu/eurostat/statistics-explained/index. php/Energy_consumption_in_households. Accessed January 29, 2018.

45. Sardianou, E. (2008). Estimating space heating determinants: An analysis of Greek households. Energy and Buildings, 40(6), 1084-1093.

46. Santin, O. G., Itard, L., \& Visscher, H. (2009). The effect of occupancy and building characteristics on energy use for space and water heating in Dutch residential stock. Energy and Buildings, 41(11), 1223-1232.

47. Leth-Petersen, S., \& Togeby, M. (2001). Demand for space heating in apartment blocks: Measuring effects of policy measures aiming at reducing energy consumption. Energy Economics, 23(4), 387-403.

48. Liao, H. C., \& Chang, T. F. (2002). Space-heating and waterheating energy demands of the aged in the US. Energy Economics, 24(3), 267-284.

49. Schuler, A., Weber, C., \& Fahl, U. (2000). Energy consumption for space heating of West-German households: Empirical evidence, scenario projections and policy implications. Energy policy, 28(12), 877-894.

50. Swan, L. G., \& Ugursal, V. I. (2009). Modeling of end-use energy consumption in the residential sector: A review of modeling techniques. Renewable and Sustainable Energy Reviews, 13(8), $1819-1835$.

51. VROM, M. (2008). Randstad 2040. Samenvatting Structuurvisie.

52. Ogunjobi, K. O., Daramola, M. T., \& Akinsanola, A. A. (2017). Estimation of surface energy fluxes from remotely sensed data over Akure, Nigeria. Spatial Information Research, 26, 1-13.

53. Kumari, M., \& Sarma, K. (2017). Changing trends of land surface temperature in relation to land use/cover around thermal power 
plant in Singrauli district, Madhya Pradesh, India. Spatial Information Research, 25(6), 769-777.

54. Ige, S. O., Ajayi, V. O., Adeyeri, O. E., \& Oyekan, K. S. A. (2017). Assessing remotely sensed temperature humidity index as human comfort indicator relative to landuse landcover change in Abuja, Nigeria. Spatial Information Research, 25(4), 523-533.

55. Qelichi, M. M., Murgante, B., Feshki, M. Y., \& Zarghamfard, M. (2017). Urbanization patterns in Iran visualized through spatial auto-correlation analysis. Spatial Information Research, 25(5), 627-633.

56. David, T. I., Mukesh, M. V., Kumaravel, S., Ramesh, G., \& Premkumar, R. (2017). Exploring 16 years changing dynamics for land use/land cover in Pearl City (Thoothukudi) with spatial technology. Spatial Information Research, 25(4), 547-554.

57. Sekac, T., Jana, S. K., \& Pal, D. K. (2017). Identifying potential sites for hydropower plant development in Busu catchment: Papua New Guinea. Spatial Information Research, 25(6), 791-800.

58. Kim, H. K., Yi, M. S., \& Shin, D. B. (2017). Regional diffusion of smart city service in South Korea investigated by spatial autocorrelation: Focused on safety and urban management. Spatial Information Research, 25(6), 837-848. 